Kumawula, Vol. 3, No.1, April 2020, Hal 1 - 6

DOI:http://10.24198/kumawula.v3i1.23961

ISSN 2620-844X (online)

Tersedia online di http://jurnal.unpad.ac.id/kumawula/issue/view

\title{
PENINGKATAN PENGETAHUAN EKSPOR BAGI PELAKU USAHA DI GARUT
}

\author{
Teuku Rezasyah $^{1}$, Ivan Darmawan ${ }^{2}$, Affabile Rifawan ${ }^{3}$ \\ ${ }^{1,3}$ Departemen Hubungan Internasional, Fakultas Ilmu Sosial dan Ilmu Politik, Universitas Padjadjaran \\ ${ }^{2}$ Departemen Ilmu Pemerintahan, Fakultas Ilmu Sosial dan Ilmu Politik, Universitas Padjadjaran \\ 1'teuku.rezasyah@unpad.ac.id, ${ }^{2}$ ivan.idevice@gmail.com, ${ }^{3}$ a.rifawan@unpad.ac.id
}

\begin{abstract}
ABSTRAK
Semenjak disepakatinya perdagangan bebas ASEAN-China (ACFTA) pada 1 Januari 2010, China mulai mendominasi perdagangan Internasional. Para pengusaha lokal memiliki ambisi untuk memajukan produk Indonesia ke pasar Internasional dengan melakukan ekspor produk ke luar negeri terutama China. Tujuan kegiatan ini adalah meningkatkan pemahaman mengenai bea cukai dan metode pengiriman barang ke luar negeri. Metode yang digunakan adalah diseminasi informasi antara pengusaha dengan fasilitator pemerintah yang diwakili oleh FTA Center Bandung dan diselenggarakan oleh Unpad. Hasilnya adalah di Kabupaten Garut, tercatat banyak sekali pengusaha muda atau warga yang baru saja merintis usaha industri. Tetapi tidak sedikit pula pengusaha lokal yang paham teknis dan strategi dalam mengeksporkan produk mereka pada pasar Internasional serta memiliki tindak lanjut ke tahap selanjutnya untuk menjalin komunikasi antara pengusaha dan FTA Center Bandung.
\end{abstract}

Kata kunci: ekspor, globalisasi, FTA Center, pengusaha

\begin{abstract}
Since the ASEAN-China free trade agreement (ACFTA) was signed on January 1, 2010, China has been starting to dominate international trade. Local entrepreneurs have ambitions to advance Indonesian products to the international market by exporting products abroad, especially China. The purpose of this activity is to increase understanding of customs and methods of shipping Indonesian goods overseas. The method is information dissemination between entrepreneurs and government facilitators represented by the Bandung FTA Center and organized by Unpad. The result was that in Garut Regency, there are many entrepreneurs who just started industrial ventures. However, only in small amount of local entrepreneurs who understand the technical and strategy in exporting their products to the international market. By this activity, it provided follow-up action plan to the next stage to establish communication between entrepreneurs and FTA Center Bandung.
\end{abstract}

Keywords: Export, Globalization, FTA Center

\section{Pendahuluan}

Pada era globalisasi seperti sekarang ini negara yang mampu terus mengikuti laju kemajuan industri salah satunya adalah negara China. Mereka mampu tumbuh menjadi negara yang menunjukkan peningkatan ekonomi di atas rata-rata, China mampu bertahan dari goncangan krisis ekonomi dunia pada akhir abad ke 20 (Lardy \& Subramanian, 2011). Kemampuannya 
untuk terus meningkatkan ekonomi dipengaruhi oleh beberapa faktor pendukung, seperti aspek politik, ekonomi, sosial, dan budaya juga memiliki peranan yang sangat penting dalam kemajuan pembangunan negara China.

Selain itu, China juga pandai memanfaatkan peluang dalam perdagangan Internasional salah satu contohnya yaitu, sejak disepakati perdagangan bebas ASEAN-China (ACFTA) yang dimulai sejak tanggal 1 Januari 2010, produk barang jadi dari China membanjiri pasar domestik ASEAN. ACFTA merupakan kesepakatan antara negara-negara anggota ASEAN dengan China untuk mewujudkan kawasan perdagangan bebas dengan menghilangkan atau mengurangi hambatan-hambatan perdagangan barang baik tarif ataupun non tarif, peningkatan akses pasar jasa, peraturan dan ketentuan investasi, sekaligus peningkatan aspek kerjasama ekonomi untuk mendorong hubungan perekonomian para pihak ACFTA dalam rangka meningkatkan kesejahteraan masyarakat ASEAN dan China. Hal ini menyebabkan kawasan perdagangan baru mulai bermunculan dan kawasan perdagangan lama juga ikut ramai. China juga dikenal sebagai negara yang menjual barang dengan harga murah karena salah satu faktor ekspor dari China ke luar negeri difasilitasi oleh pemerintahnya (Chin dan Stubbs, 2011). Faktanya,China dalam beberapa komoditi mampu mendominasi impor ke negara-negara berkembang maupun maju, salah satunya adalah Indonesia yang menjadi target pemasaran produk-produk China hingga saat ini.

Dapat disimpulkan bahwa China sebenarnya adalah potensi pasar yang cukup besar. Maka diperlukan adanya upaya peingkatan kapasitas dan fasilitas oleh pemerintah dengan cara mempererat hubungan kerjasama dengan China di berbagai sektor penting, sehingga dapat terjadi keseimbangan antara kedua negara didukung dengan pembekalan ilmu seperti dilaksanakan sosialisasi kepada pengusaha lokal agar mereka siap bersaing dalam pasar internasional.

\section{Metode}

Dalam melaksanakan kegiatan ini, dibutuhkan persiapan selama satu bulan untuk mengobservasi dan sharing session pengusaha tentang kebutuhan apa saja yang diperlukan dalam melaksanakan ekspor. Selain itu, dibutuhkan juga waktu untuk perizinan tempat serta komunikasi dengan FTA Center agar pelaksanaan acara berjalan lancar. Kegiatan ini berlangsung dari Bulan Juli sampai dengan Agustus 2019. Kegiatan ini melibatkan peneliti sebagai pembimbing dan mahasiswa KKN sebagai pelaksana kegiatan sebanyak 8 orang. Untuk peserta kegiatan adalah pengusaha yang ada di Garut yang berada di bawah naungan 
HIPMI Garut dan pengusaha olahan kulit. FTA Center dilibatkan sebagai pemberi materi pelatihan sebagai fasilitator dari pihak pemerintah yang dapat membantu pengusaha agar proses ekspornya lebih mudah.

Berikut ini kegiatan observasi dan sharing session dengan pengusaha:
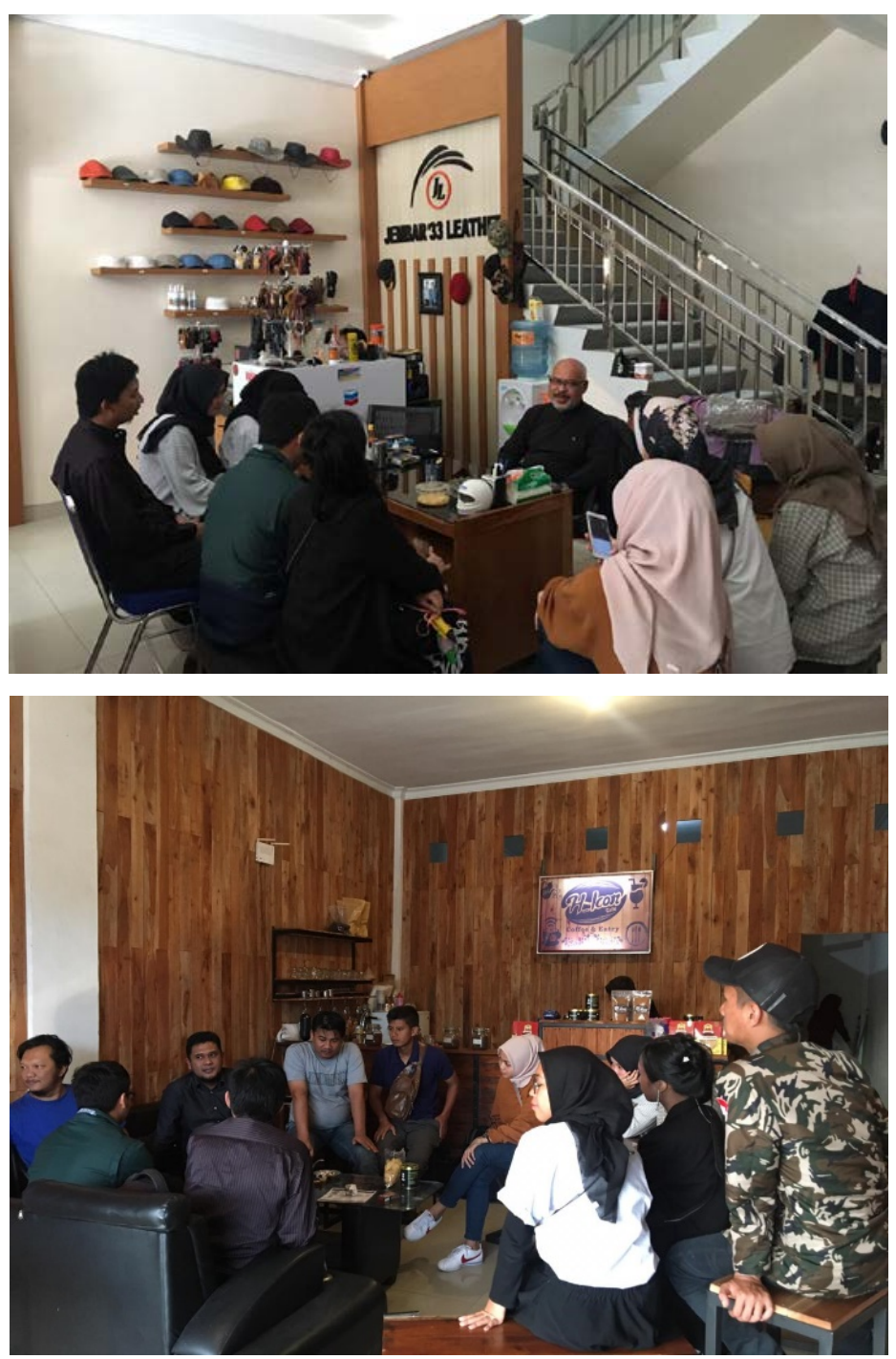

Sementara itu, untuk kegiatan sosialisasi ini dilakukan dalam satu hari, yaitu presentasi mengenai sosialisasi ekspor ke luar negri terutama China. Persiapan yang kami lakukan yaitu mendatangi mitra yang akan menjadi peserta sosialisasi tersebut. Mitra yang kami datangi yaitu pengusaha kulit dan HIPMI (Himpunan Pengusaha Muda Indonesia) Garut. Kemudian, kami membentuk struktur kepanitiaan agar kerja kami bisa berjalan dengan baik. Setelah itu kami melakukan pemilihan tempat dan barang apa saja diperlukan dalam pelaksanaan. Persiapan materi yang akan disampaikan dilakukan oleh peneliti dan FTA Center Bandung. Isi penyuluhan terfokus pada kegiatan memberikan pengetahuan mengenai ekspor ke luar negri terutama ke Negara China. 
Berikut ini kegiatan pada saat sosialisasi berlangsung:
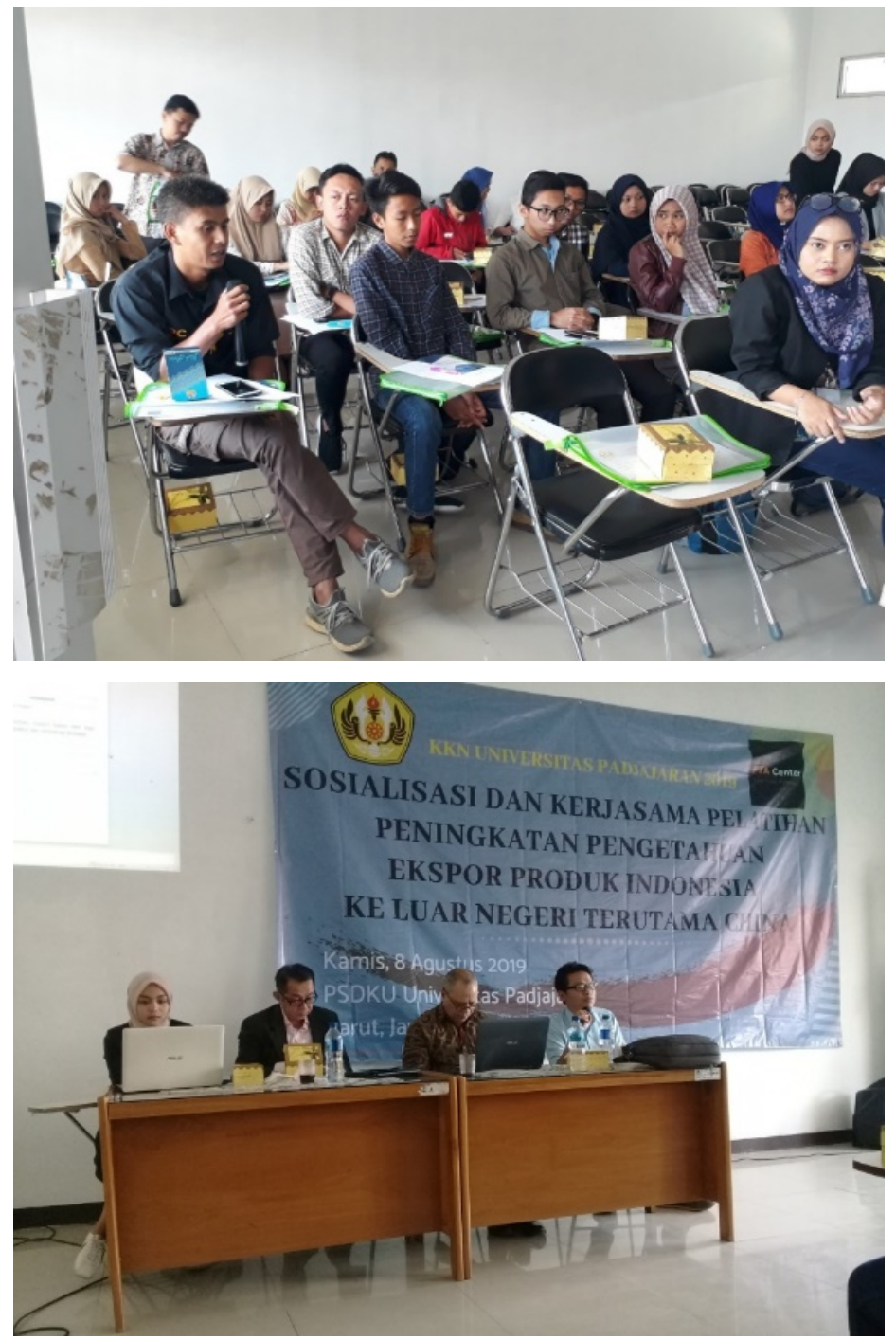

\section{Hasil}

Pada era globalisasi sekarang, semenjak disepakatinya perdagangan bebas ASEAN-China (ACFTA) pada 1 Januari 2010, China mulai mendominasi perdagangan Internasional. Para pengusaha lokal memiliki ambisi untuk memajukan produk Indonesia ke pasar Internasional dengan melakukan ekspor produk ke luar negeri terutama China. Aspek yang sangat penting untuk dipahami dalam melakukan kegiatan ekspor produk adalah pemahaman mengenai bea cukai dan metode pengiriman barang ke luar negeri terutama China. Di Kabupaten Garut, tercatat banyak sekali pengusaha muda atau warga yang baru saja merintis usaha industri. Tetapi tidak sedikit pula pengusaha lokal yang belum paham teknis dan strategi dalam mengeksporkan produk mereka pada pasar Internasional. 
Berdasarkan permasalahan yang dipaparkan di atas, maka dilakukan sosialisasi dan kerjasama pelatihan peningkatan pengetahuan terutama ekspor produk Indonesia ke luar negeri terutama ke China di Kabupaten Garut yang dihadiri oleh 25 peserta di Aula Kampus Universitas Padjajaran, Garut. Pemberian materi yang dilakukan adalah mengenai cara meningkatkan pengetahuan tentang hal-hal yang berkaitan dengan ekspor secara teoritis dan praktikal. Selanjutnya, materi kedua yang disampaikan adalah mengenai promosi dan pemasaran produk ekspor Jawa Barat. Sebelum dimulai acara peserta diberi kertas yang berisi quisioner oleh FTA yang berisi tentang hal-hal yang berhubungan dengan usaha. Setelah semua materi diberikan, dibuka sesi tanya-jawab antara peserta sosialisasi dengan narasumber dan semua peserta aktif untuk bertanya dan peserta memahami materi dengan baik. Hal yang terjadi juga adalah adalah tindak lanjut dari peserta kegiatan dengan langsung follow up kegiatan usahanya untuk ekspor dengan fasilitas yang diberikan oleh FTA Center. Pertemuan dua mitra ini sangat penting untuk keberlangsungan manfaat dari kegiatan ini.

Hal yang unik dalam kegiatan ini Unpad khususnya menjalankan fungsi menjembatani antara pengusaha sebagai pelaku di lapangan yang memberikan sumbangsih bagi perekonomian sekitarnya dan FTA Center Bandung sebagai bagian dari pemerintah yang merupakan kepanjangan dari Kementrian Perdagangan untuk memberdayakan para pengusaha agar produk-produknya bisa ekspor ke luar negeri sehingga bisa berkontribusi positif terhadap perekonomian Indonesia. Walaupun tidak menjadi focal point, akan tetapi posisi Unpad dalam hal ini cukup tepat karena Unpad sifatnya lebih banyak memberi masukan sesuai kaidah teoritis dan ilmiah sementara praktiknya akan lebih baik jika para pihak yang berwenang dan berkompeten saling bekerjasama. Dalam hal ini para pengusaha dan pemerintah melalui FTA Center.

\section{Kesimpulan}

Bersamaan dengan kegiatan Kuliah Kerja Nyata (KKN), pengabdian kepada masyarakat ini dapat menjadi tempat bagi mahasiswa untuk menerapkan disiplin ilmu nya dan dengan adanya KKN ini, diharapkan mahasiswa dapat berperan dan berpartisipasi secara aktif dalam masyarakat sebab di masyarakat tidak hanya ilmu yang perlu diterapkan tetapi bagaimana cara mahasiswa menyatu dengan lingkungan masyarakat.

Lebih lanjut dalam pelaksanaan kegiatan ini kami juga mengajak seluruh pengusaha kabupaten Garut untuk follow up kegiatannya dengan FTA Center agar lebih nyata manfaatnya. Diharapkan kegiatan ini bisa membantu mengembangkan potensi yang ada di 
kabupaten Garut dan dapat melaksanakan ekspor ke pasar internasional terutama Cina dengan fasilitasi dari pemerintah.

\section{Ucapan Terima Kasih}

Penulis berterima kasih banyak kepada Universitas Padjadjaran yang telah memberikan skema pendanaan untuk pengabdian masyarakat yang terintegrasi dengan Hibah Internal Unpad. Selain itu juga kami apresiasi kerjasama yang telah dilakukan dengan FTA Center Bandung, HIPMI Garut, dan PSDKU Unpad Garut.

\section{Daftar Pustaka}

Chin, G., \& Stubbs, R. (2011). China, regional institution-building and the China-ASEAN Free Trade Area. Review of International Political Economy, 18(3), 277-298.

Lardy, N. R. \& Subramanian, A., 2011. Sustaining China's Economic Growth After the Global Financial Crisis. Washington DC: Peterson Institute.

Peraturan Presiden No.57 Tahun 2010 tentang Pengesahan ASEAN-China Investment Agreement. 